\title{
The Role of the African Languages Research Institute in Addressing Language of Instruction Dilemmas in Zimbabwe
}

Jesta Masuku, Department of African Languages and Culture, Midlands State University, Gweru, Zimbabwe (jestamasuku@hotmail.com) and

Finex Ndhlovu, School of Languages, Cultures and Linguistics, Monash University, Clayton Campus, Melbourne, Australia

(finex.ndhlovu@arts.monash.edu.au)

\begin{abstract}
The lexicographic work of the African Languages Research Institute (ALRI) has played a significant role in attempting to avoid some of the dilemmas associated with using African languages as media of instruction in the Zimbabwean education system. Monolingual Shona and Ndebele dictionaries, biomedical reference works, dictionaries of musical, literary and linguistic terms as well as children's dictionaries constitute part of ALRI's contribution towards the goal of mainstreaming African languages in the education system. This article is an evaluation of the research activities taking place at ALRI. The aim of the article is to demonstrate that if they receive adequate attention through corpus planning, African languages possess the capacity to play an important role as media of instruction across the entire spectrum of the education curricula in Zimbabwe and elsewhere. The article concludes by observing that, if the efforts of ALRI are to succeed, there is need for the co-operation of all stakeholders in language practice.
\end{abstract}

Keywords: DICTIONARIES, LEXICOGRAPHY, LEXICOGRAPHER, LEXICOGRAPHIC RESEARCH, INDIGENOUS AFRICAN LANGUAGES, AFRICAN LANGUAGES RESEARCH INSTITUTE (ALRI), EDUCATION, CURRICULUM, MEDIUM OF INSTRUCTION, SHONA, NDEBELE, ZIMBABWE

Opsomming: Die rol van die African Languages Research Institute by die hantering van onderrigtaaldilemmas in Zimbabwe. Die leksikografiese werk van die African Languages Research Institute (ALRI) het ' $n$ betekenisvolle rol gespeel om sommige van die dilemmas te probeer vermy wat gepaard gaan met die gebruik van Afrikatale as onderrigmedia in die Zimbabwiese opvoedingstelsel. Eentalige Sjona- en Ndebelewoordeboeke, biomediese naslaanwerke, woordeboeke van musiek-, letterkunde- en taalkundeterme sowel as woordeboeke vir kinders maak deel uit van ALRI se bydrae tot die doelwit om Afrikatale in die hoofstroom van die opvoedingstelsel te plaas. Hierdie artikel is 'n beoordeling van die navorsingsaktiwiteite wat by ALRI plaasvind. Die doel van die artikel is om te toon dat, indien hulle voldoende aandag deur korpusbeplanning ontvang, Afrikatale die vermoë besit om 'n belangrike rol as onderrigmedia oor die hele spektrum van die opvoedingsleerplanne in Zimbabwe en elders te speel. Die artikel sluit 
met die waarneming dat, indien die pogings van ALRI wil slaag, daar behoefte is aan die samewerking van alle belanghebbendes in die taalpraktyk.

Sleutelwoorde: WOORDEBOEKE, LEKSIKOGRAFIE, LEKSIKOGRAAF, LEKSIKOGRAFIESE NAVORSING, INHEEMSE AFRIKATALE, AFRICAN LANGUAGES RESEARCH INSTITUTE (ALRI), OPVOEDING, LEERPLAN, ONDERRIGMEDIUM, SJONA, NDEBELE, ZIMBABWE

\section{Introduction}

The question of developing indigenous African languages for literacy and education has remained a continuing challenge for most postcolonial African nations. Arguments for and against the use of African languages in the school system have been advanced over the years. That there is a need for the use of African languages in all socio-cultural domains and more so in education, has directed and defined paradigms for language policy formulation for many African states. For instance, early in the 1980s, crucial Pan-African conferences on education advanced useful recommendations regarding the issue of mainstreaming African languages in education systems. The 1984 Pan-African Conference on Education held in Yaoundé, Cameroon, on the theme What School for Africa in the Year 2000?, critically reviewed the language issue in African education systems. The following year, 1985, the Organization of African Unity (OAU) in the same spirit adopted the Language Plan of Action for Africa (see Hartell 1993: v). In this plan, the desire to uplift the institutional and functional status of African languages was emphasized. African member states were encouraged to define their own language policies.

However, it is disappointing that for the majority of African states today, the goal of making these languages viable tools of literacy and education has largely remained mere intention yet to be put into concrete action (King'ei 2001: 122). In the case of Zimbabwe, the African Languages Research Institute (ALRI) has played a leading role in attempting to meet the ideals of the Language Plan of Action for Africa. The ongoing lexicographic work at ALRI is one of the pragmatic ways of preparing African languages for wider socio-economic and cultural functions in Zimbabwean national life.

This article, therefore, looks at how the important area of African language lexicography has been placed at the centre of research activities in Zimbabwe. On the part of ALRI, lexicography is viewed as the missing piece in and possible solution to the puzzle associated with the successful use of African languages as media of instruction in African education systems.

For the examination of the contribution of ALRI in addressing the dilemmas regarding the language of instruction in Zimbabwe, this article is organized as follows. The first section gives an overview of the connection between African lexicography and the education curricula. This is followed by a section specifically focusing on how ALRI's activities have so far tried to address the 
dilemma of the language of instruction in Zimbabwe. Some of the subthemes covered under this section include an enumeration of completed and ongoing ALRI projects, the dichotomy of lexicography and language policies as well as the role of lexicography in facilitating language acquisition. The article concludes with a statement pointing to future challenges related to the use of African languages as media of instruction.

\section{An overview of the potential role of African language lexicography in education}

The interplay existing between lexicography, the school curriculum and its subsequent link to the language of instruction in African education systems cannot be over-emphasized. General lexicography concerns itself with the design, use, and compilation of lexicographic reference works as well as the task of evaluating their function and relevance in user communities. African language lexicography goes even a step further in its activities, aiming at the development and documentation of terminologies in various fields, even those fields previously deemed beyond the reach of indigenous languages. In trying to keep pace with scientific and technological advancements, lexicography in the African languages has indeed gone a long way in showing that languages can be manipulated to adapt to the ever-changing scientific and technological advancements in many modern societies. Furthermore, they have shown that indigenous African languages can be promoted to the same level as any other language considered as developed (ALRI Newsletter August 2005: 1). This indeed is an indicator of the strong connection between lexicography and the use of indigenous languages in education. Realizing the interplay that exists between lexicography and the use of indigenous languages as media of instruction in African education systems, Ngara (1982: 133) observes:

[Indigenous] languages should be developed to meet the needs of a modern state and this demands that the vocabulary of these languages be elaborated and modernized ... giving words a scientific orientation, expanding the vocabulary and compiling dictionaries.

With specific reference to Shona, Ngara emphasizes that the use of indigenous languages as media of wider communication is not merely a process of creating appropriate equivalents. These terms should be uniform and be approved by the majority of the users. To this effect Ngara (1982: 135) says:

It is vital that the terms be standardized and be known by the users of the language ... I will recommend that a dictionary of modern Shona terminology be compiled.

The rationale for this is that the use of lexicographic reference works such as dictionaries is an authentic, fast and reliable way of spreading information 
about new scientific and technological terms and providing a quick reference for students, translators, media practitioners and others in varying spheres of life. This means that the compilation of lexicographic reference works is indeed a necessary prerequisite for the successful use of African languages as media of instruction in schools. Some of the aspects identified by Ngara such as expanding vocabularies through term creation, developing languages to meet the needs of modern society and ultimately the compilation of dictionaries, happen to lie in the special preserve of lexicography.

The dichotomy of lexicography and education can also be observed in the recommendations made by the delegates to the 1984 Pan-African Conference on Education. In encouraging the development and use of African languages in education, the delegates noted the important role played by African universities in organizing research on these languages. Above all, they recommended the documentation of African languages to make them more functional in society. Obanya (1984: 13) suggested:

The use of African languages for teaching and learning should be intensified and there should be documentation of African languages to make them functional.

That most lexicographic activities in Africa and indeed elsewhere in the world, consist of research carried out by professionals and academics connected to university research units is not a mere coincidence, but an indicator of the strong relationship existing between the disciplines of lexicography and education. In further emphasizing this connection the mission statement of ALRI (Chimhundu 2003: 4) reads as follows:

To research, document and develop Zimbabwean indigenous languages in order to promote and expand their use in all spheres of life.

What emerges from the foregoing is that the development of reference works in the form of orthographies, scientific and technical terminologies and dictionaries constitutes a solid foundation for the successful use of African languages in education. Most important is that these also form part of the essential activities in the field of lexicography. In the following section, the possibility of addressing the dilemma of the language of instruction by using lexicography is further explored.

\section{ALRI's contribution to addressing the dilemma of language of instruc- tion through lexicography}

This section reviews the lexicographic research projects undertaken by the African Languages Research Institute, discusses their impact on language terminologies, and provides suggestions on how education systems in Zimbabwe and indeed the rest of Africa could take as example its approaches to addressing the problem of language of instruction. 


\subsection{Background to the research activities of ALRI}

ALRI is a non-faculty and non-teaching research institute at the University of Zimbabwe, whose major mandate is to research Zimbabwean African languages with a view to documenting and developing them to promote and expand their overall use (Chimhundu 2003: 4). While major research activities have been in the two national languages, Shona and Ndebele, research has also been extended to minority languages like Kalanga, Nambya and Shangani.

The following is a list of research projects that have been completed, those that are in progress, as well as those planned for the future.

Seven lexicographic research projects, which resulted in the publication of the following dictionaries, have been completed:

(a) Duramazwi reChiShona (1996) - Shona Monolingual Dictionary.

(b) Duramazwi Guru reChiShona (2001) - Advanced Shona Monolingual Dictionary.

(c) Isichazamazwi SesiNdebele (2001) - Ndebele Monolingual Dictionary

(d) Duramazwi reUrapi neUtano (2004) - Shona Biomedical Terms Dictionary.

(e) Duramazwi reMimhanzi (2005) - Dictionary of Shona Musical Terms.

(f) Isichazamazwi SezoMculo (2006) - Dictionary of Ndebele Musical Terms.

(g) Duramazwi reDudziramutauro neUvaranomwe (2007) - Dictionary of Shona Linguistic and Literary Terms.

Two projects are currently in progress:

(a) Isichazamazwi SesiNdebele Esilolongwe Sengezwa (Forthcoming) - Revised and Enlarged Ndebele Monolingual Dictionary.

(b) Duramazwi reVana — Shona Children's Dictionary.

Several projects are planned for the future:

(a) Ndebele Advanced Monolingual Dictionary.

(b) Ndebele Biomedical Terms Dictionary.

(c) Ndebele Linguistic and Literary Terms Dictionary.

(d) Ndebele Children's Dictionary.

(e) Shona and Ndebele Mathematics Dictionaries.

It is anticipated that there will also be a focus on more terminological dictionaries in various specialist fields, including health, agriculture, law, commerce, environmental studies, natural sciences and other academic and vocational subjects. 
This focus of ALRI is deliberately directed towards ensuring that the African languages of Zimbabwe are developed into relevant media of instruction for use across the entire spectrum of the country's education system.

\subsection{Relevance of the research activities to language policy and curriculum issues}

A review of the research activities of ALRI in addressing the language of instruction dilemma shows lexicography going beyond its traditional task of dictionary-making into the realm of language planning and development. The question is: How can these activities benefit the education system? The following is a discussion of ALRI's impact on curriculum and language policy issues.

\subsubsection{Linking lexicography to the schools' curriculum}

The various lexicographic projects in the Zimbabwean indigenous languages have paid close attention to the demands of the schools and higher education curricula. With regard to this, various dictionaries covering terms used in different disciplines offered in Zimbabwean schools, colleges and universities have been compiled or planned. The Shona Children's Dictionary, Duramazwi reVana, for instance, targets primary school children falling between the ages of 9 and 13. The main focus of this dictionary has been to select international terms and provide their indigenous language equivalents. The children are subjected to terms used internationally but have the concepts explained in a meaningful language they best understand. Secondary school and tertiary education students will also benefit from the general and specialized dictionaries which treat literary, linguistic, musical, scientific and mathematical concepts, to mention a few of the subject disciplines covered.

While the lexicographers are in the process of compiling these dictionaries, they also have close consultation with the classroom practitioners and curriculum specialists. This enables the lexicographers to obtain simultaneous feedback from the users while the compilation process is still in progress, thus making the reference work an agreed-upon and user-friendly product. With terms captured from the majority of the subject disciplines in the schools' curriculum, lexicography has provided essential references naming and describing varied phenomena in the local languages.

\subsubsection{Vocabulary acquisition}

Vocabulary acquisition is important in all language teaching and language enhancement initiatives and even more important in the use of these languages as media of instruction in schools. Teachers have to help their students in accumulating a wide vocabulary in using indigenous languages. The dictionary, therefore, becomes one of the most reliable sources for enhancing vocabulary 
growth. Once vocabulary growth in the use of African languages has been increased through dictionaries, the ability of using these languages confidently and understanding certain concepts is easy.

\subsubsection{Fighting negative attitudes}

Attitude problems in the use of indigenous languages in various spheres, even the sphere of education, have a long history. However, these problems are not insurmountable. ALRI's research activities in lexicography have countered the mutual attitudes between the once believed low status of indigenous African languages and the high profile disciplines of science. This is seen in the collaborative efforts made by African language lexicographers and medical professionals resulting in the production of the first Shona Biomedical Terms Dictionary, Duramazwi reUrapi neUtano. This dictionary was compiled specifically to help combat communication problems experienced between medical doctors and their patients, some of whom neither speak nor understand English. The Shona biomedical terms presented in this dictionary have undoubtedly enhanced the doctors' communicative competence in using as well as in explaining medical terms in a local language. This resource, although initially targeted at medical practitioners and medical students, can be useful to anyone wanting to use indigenous languages to describe abstract technical and scientific phenomena. Not only do users comfortably express themselves in an indigenous language, but they also shed off their previously held negative notions about what local languages can do and are capable of doing.

Another example of how an indigenous language can be and is capable of being used in the field of science, is the inventory of Ndebele physics terms compiled by an academician at the National University of Science and Technology in Bulawayo. This academician, through collaborative research has provided ALRI with the terms which he uses in his physics lectures. These terms, being standardized and elaborated through seminars held with other science teachers and lecturers, have been incorporated into the Advanced Ndebele Dictionary (AND) database. Furthermore, the same academician has translated his Ph.D. thesis in physics into Ndebele. Hadebe (2004) notes that if teachers and professionals are to change attitudes, they would normally require evidence based on research to convince society of the importance of mothertongue instruction. What better evidence would the user community require than being shown the extent to which these languages can be and are capable of being used as media of instruction?

The appearance of the first monolingual dictionaries in Shona and Ndebele was received with great enthusiasm. Speaking of the publication of the Ndebele dictionary, Hadebe (2004: 102) observes:

For many Ndebele-speaking people, the publication of the dictionary marked the revival of their language and culture from what is perceived as cultural oppression. The dictionary was considered with national pride. 
He further notes that dictionaries must go beyond being mere symbols of national pride and become actual tools of communication. If this is achieved, then dictionaries can be seen as having created a conducive linguistic climate for decisive changes in education policies to be initiated as policy makers would be taking these decisions from an informed position.

\section{Conclusion}

The commitment of African governments to develop African languages as shown in their blueprint policies has been noted in the article. Although the complexity of the language situation in many countries must be borne in mind, the use of national languages can help in the universalization and democratization of education in Africa. The efforts made in African language lexicography to develop and document the Zimbabwean languages for use in education have also been assessed. The article has shown that any language can eventually be used as a language of instruction provided it has a recognized orthography and its structure is described. For such a language to be suitable for technical and scientific teaching, there has to be stages of fundamental and applied research, and experimentation in term creation leading to the standardization and elaboration of such terms. Fortunately for the Zimbabwean education system, ALRI has already undertaken such research in the field of lexicography. This greatly contributes to addressing the dilemma of the language of instruction in African education systems. However, more work still lies ahead as Brock-Utne (1993: 30), relating the secret behind the success of the Norwegian experience, points out:

In education at the University of Oslo ... none of the books on the required reading list were written in Norwegian. One was Swedish and the rest were English. Together with our professor, we scrutinized difficult English terminology within the professional field of education, found equivalent Norwegian terms and sometimes coined new words. Twenty years later most of the books on the reading list were Norwegian ... It is important that we use our own languages ... and if we stop doing that, the language will not develop and will be less fit as an academic tool.

What is most important now is a complete revision of education policies to acknowledge and reassess the position of African languages as media of instruction.

\section{References}

ALRI Newsletter. 2005. Award Winning at the 2005 Zimbabwe International Book Fair. August Edition. Harare: African Languages Research Institute.

Brock-Utne, B. 1993. Education in Africa: Education for Self-reliance or Recolonization? Blindern: University of Oslo. 
Chimhundu, H. 2003. Report on the Retreat to Review the ALLEX Project. Harare: African Languages Research Institute.

Hadebe, S. 2004. Improving Dictionary Skills in Ndebele. Lexikos 14: 89-104.

Hartell, R.L (Ed.). 1993. Alphabets of Africa. Dakar: UNESCO/Summer Institute of Linguistics.

King'ei, K. 2001. Challenges and Opportunities in the Development of African Languages in Kenya. Mdee, J.S. and H.J.M. Mwansoko (Eds.). 2001. Makala Ya Kongamano La Kimataifa: Kiswahili 2000 Proceedings: 122-133. Dar es Salaam: Chuo Kikuu.

Ngara, E.A. 1982. Bilingualism, Language Contact and Planning: Proposals for Language Use and Language Teaching in Zimbabwe. Gweru: Mambo Press.

Obanya, P. 1984. The Problem of Relevance in the African Schools Programme. What School for Africa in the Year 2000? Report of the Proceedings of the Pan-African Conference on Education (Yaoundé, Cameroon, 2-9 April 1984): 142-165. Morges: World Confederation of Organizations of the Teaching Profession. 